\title{
FEED FORWARD NEURAL NETWORK SEBAGAI ALGORITMA ESTIMASI STATE OF CHARGE BATERAI LITHIUM POLYMER
}

\author{
Mohammad Imron Dwi Prasetyo, Novie Ayub Windarko, Anang Tjahjono \\ Politeknik Elektronika Negeri Surabaya \\ Kampus PENS Jl. Raya ITS Sukolilo, Surabaya, 60111 \\ e-mail: imronz65@gmail.com
}

\begin{abstract}
Battery State Of Charge (SOC) estimation is the most important parameter in the Battery Management System (BMS), especially as an application of electric vehicles and smart grid. SOC can't be measured directly, so an estimation method is needed to obtain this value. Some methods that have been proposed are coloumb counting and open circuit voltage. However coloumb counting has a weakness in the initial SOC initialization and has a dependency on the current sensor. While the open circuit voltage method can only be used on batteries in idle conditions. This research proposes the method of Feed Forward Neural Network (FFNN) algorithm for estimating SOC lithium polymer batteries. This algorithm can solve nonlinear systems such as those of lithium polymer batteries. The FFNN architecture was built twice (dual neural) for the estimation of OCV and SOC. The first FFNN with input voltage, current, and charging or discharging times for OCV estimation. The first OCV neural training results are used as the second FFNN input for SOC estimation. The results of this estimation are obtained with the value of hidden neurons 11 in the first neural and hidden neurons 4 in the second neural.
\end{abstract}

Keywords: SOC, BMS, Coloumb Counting, OCV, FFNN

\begin{abstract}
Abstrak
Estimasi State of Charge (SOC) baterai merupakan parameter terpenting dalam Battery Management System (BMS), terlebih sebagai aplikasi dari mobil listrik dan smart grid. SOC tidak dapat dilakukan pengukuran secara langsung, sehingga diperlukan metode estimasi untuk mendapatkan nilai tersebut. Beberapa metode yang pernah diusulkan adalah coloumb counting dan open circuit voltage. Akan tetapi coloumb counting memiliki kelemahan dalam hal inisialisasi SOC awal dan memiliki ketergantungan terhadap sensor arus. Sedangkan metode open circuit voltage hanya dapat digunakan pada baterai dalam kondisi idel. Pada penelitian ini diusulkan metode algoritma Feed Forward Neural Network (FFNN) untuk estimasi SOC baterai lithium polymer. Algoritma ini dapat menyelesaikan sistem nonlinier seperti yang dimiliki oleh baterai lithium polymer. Arsitektur FFNN dibangun dua kali (dual neural) untuk estimasi OCV dan SOC. FFNN pertama dengan input tegangan, arus, dan waktu charging maupun discharging untuk estimasi OCV. OCV hasil training neural pertama digunakan sebagai input FFNN kedua untuk estimasi SOC. Hasil dari estimasi ini didapatkan dengan nilai hidden neuron 11 pada neural pertama dan hidden neuron 4 pada neural kedua.
\end{abstract}

Kata kunci: SOC, BMS, Coloumb Counting, OCV, FFNN 


\section{PENDAHULUAN}

Perkembangan teknologi di bidang transportasi seiring dengan berjalanya waktu semakin pesat. Pesatnya perkembangan tersebut tidak lepas dari banyaknya penelitian terkait dengan mode transportasi dengan sumber bahan bakar non BBM (Bahan Bakar Minyak). Salah satu aspek yang melatarbelakangi adalah tingkat kebutuhan energi BBM yang terus meningkat. Bahkan BPPT (Badan Pengembangan dan Pengkajian Teknologi) telah merilis pangsa kebutuhan energi di tahun 2050 masih menjadikan BBM sebagai primadona energi sebesar 40,1\% dari total kebutuhan energi nasional [1].

Mobil Listrik merupakan mode transportasi yang tidak menggunakan sumber BBM, ramah lingkungan, minim polusi, serta bersifat rechargeable. Dalam mobil listrik, baterai jenis lithium menjadi satu hal parameter penting sebagai energy storage. Baterai dalam system mobil listrik yang disebut sebagai Battery Management System (BMS) harus memiliki efeisiensi tinggi, keamanan yang terjamin, serta meningkatkan kehandalan untuk menghindari adanya over charge dan over discharge [2]. Pemodelan dari BMS yang cukup krusial adalah estimasi State Of Charge (SOC).

SOC merupakan prosentase yang merepresentasikan perbandingan kapasitas baterai terhadap kapasitas nominalnya. Pada prinsipnya SOC tidak dapat dilakukan secara direct measureable. Oleh karenanya estimasi SOC baterai sangat tergantung dari parameter metode dan algoritma yang digunakan. Dalam penelitian [3] mengklasifikasikan tiga pendekatan metode untuk estimasi SOC baterai. Pertama adalah coloumb counting yang secara estimasi melakukan akumulasi perhitungan jumlah muatan arus yang keluar atau masuk ke baterai terhadap waktu. Metode ini memiliki ketergantungan terhadap kepresisian dari sensor arus. Kedua adalah machine learning yang mampu melakukan estimasi secara riil time dan lebih akurat. Ketiga adalah nonlinier observer yang identik dengan memodelkan baterai secara matematik terlebih dahulu sebelum dilakukan estimasi.

Beberapa penelitian mengenai estimasi SOC baterai yang telah banyak digunakan adalah metode coloumb counting [4]-[6]. Dalam penelitian [4]-[6] juga mengevaluasi hasil koreksi metode coloumb counting yang memiliki error akibat error kumulatif dan inisialisasi SOC awal. Hal lain juga akibat dari ketidak linieran karakteristik hubungan antara SOC-OCV (State Of Charge - Open Circuit Voltage) baterai. Fungsi SOC-OCV mewakili sebuah baterai tertentu, dan umumnya merupakan fungsi monoton nonlinear antara SOC dan OCV untuk semua LIBs [7]. Oleh karena itu banyak digunakan dalam baterai sistem manajemen (BMS) untuk mengoreksi perhitungan SOC [7].

Disisi lain metode seperti Open Circuit Voltage (OCV) juga kerap kali digunakan. Metode ini mampu mengukur SOC baterai hanya pada saat baterai pada posisi open circuit. Sedangkan dalam baterai yang beroperasi pada mobil listrik senantiasa mengalami state charge condition dan discharge condition.

Dalam upaya estimasi sistem yang memiliki karakteristik nonlinier dan uncertainty dari sebuah baterai adalah machine learning yang memiliki kemampuan komputasi yang handal [8]. Neural Network merupakan contoh dari 
machine learning yang mampu menyelesaikan sistem nonlinier dengan memiliki topologi struktur yang simple [9]. Algoritma Neural Network merupakan salah satu kecerdasan buatan yang terinspirasi dari saraf (neuron) dan operasioperasinya. NN telah terbukti menjadi alat pemodelan data yang kuat, yang mampu menangkap serta mewakili hubungan masukan (input) dan luaran (output) yang kompleks dengan training data secara komputasi.

Pada penelitian ini membahas metode Feed Forward Neural Network (FFNN) sebagai algoritma estimasi SOC baterai lithium polymer. Metode ini digunakan sebagai estimasi OCV dan estimasi SOC baterai. Estimasi OCV dilakukan dengan input layer tegangan, arus, dan waktu charging maupun discharging baterai. Input tersebut diperoleh dari hasil pengujian pulsa baterai lithium polymer 1300 mAh 3 sell rating arus 1 C. Sedangkan untuk estimasi SOC baterai dengan input OCV berdasarkan kurva karakteristik OCV-SOC.

\section{METODOLOGI PENELITIAN}

\subsection{Pengambilan Data Pengujian Pulsa Baterai}

Penelitian ini berangkat dari pengambilan data melalui pengujian pulsa baterai lithium polymer 1300 mAh 3 sell kondisi charging maupun discharging sebesar $1 \mathrm{C}$ atau 1,3 A. Pengujian dilakukan dengan charging baterai mulai tegangan 11,1 volt hingga penuh pada tegangan charging 12,6 volt dengan arus konstan 1,3 A selama 40 menit. Baterai di discharge dengan arus konstan 1,3 A selama 40 menit hingga mencapai tegangan discharging 11,1 volt. Untuk mendapatkan hasil pulsa sebanyak 10 kali sebagai representasi dari SOC 0\% sampai $100 \%$ dengan step kenaikan 10\%, maka waktu charging maupun discharging 40 menit tersebut dibagi dengan 10. Sehingga besarnya pulsa charinging maupun discharging baterai selama 4 menit. Gambar 1 merupakan foto pengujian pulsa baterai lithium polymer.

Peralatan yang digunakan dalam penelitian adalah GW Instek PSW-Series Programmable Switching DC Power Supply untuk melakukan charging baterai, DC Electronic Load Rigol DL3021 untuk membebani baterai secara constan current, Oscilloscope Yokogawa DL850 untuk merekam sinyal pulsa tegangan dan arus terhadap waktu baik pada state charge maupun discharge baterai. Dan objek penelitian itu sendiri yakni baterai lithium polymer 1300 mAh 3 sell yang akan diestimasikan SOC-nya. Gambar 2 merupakan hasil pengujian pulsa baterai pada state charging serta discharging. 
Kumpulan jurnaL Ilmu Komputer (KLIK)

Volume 07, No. 1 Februari 2020

ISSN: 2406-7857

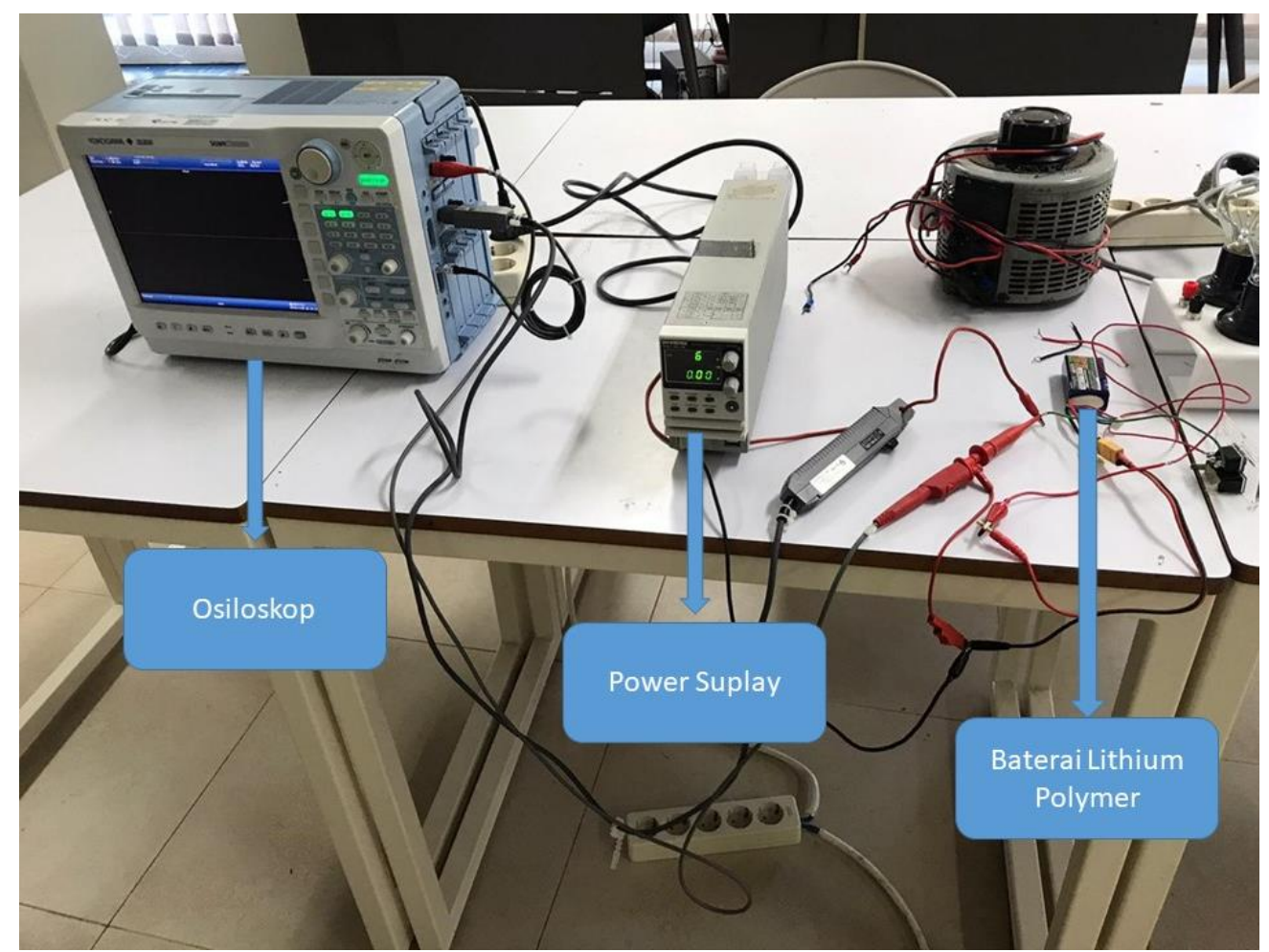

(a)

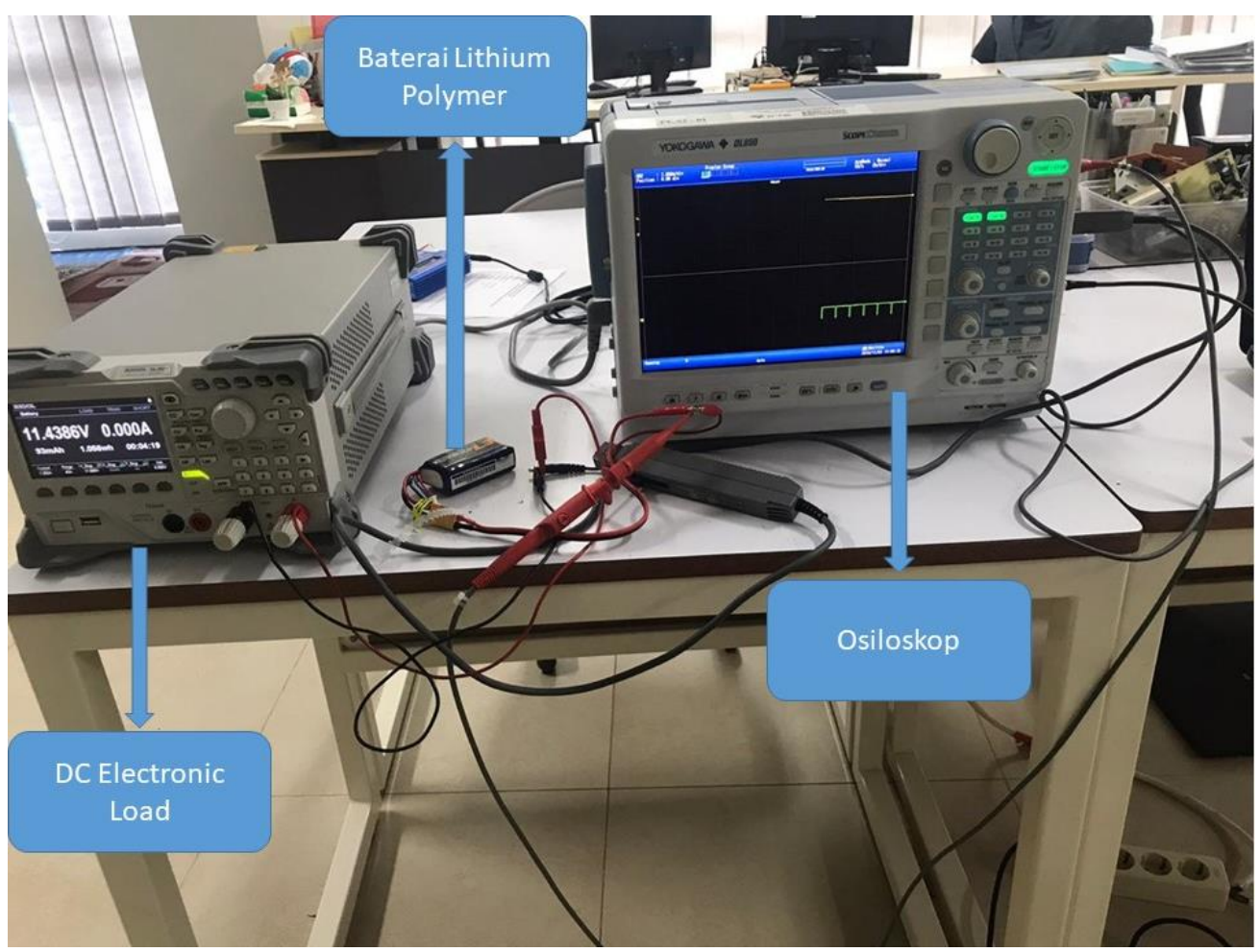

(b)

Gambar 1. Foto Pengujian Pulsa Baterai Lithium Polymer (a) Charging, (b) Discharging 


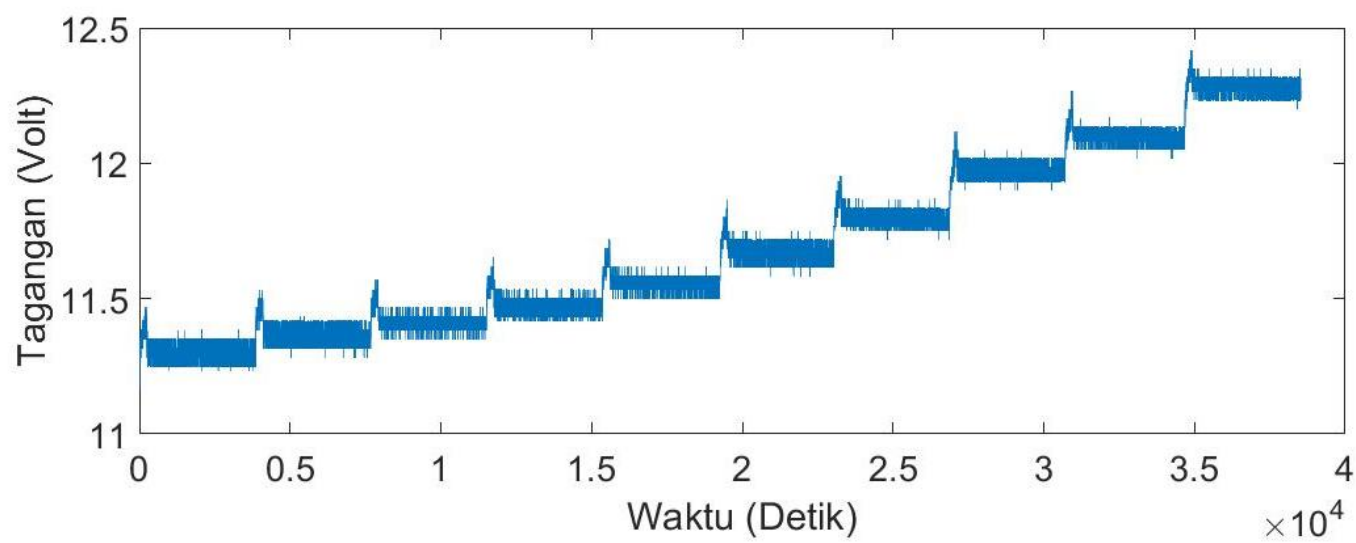

(a)

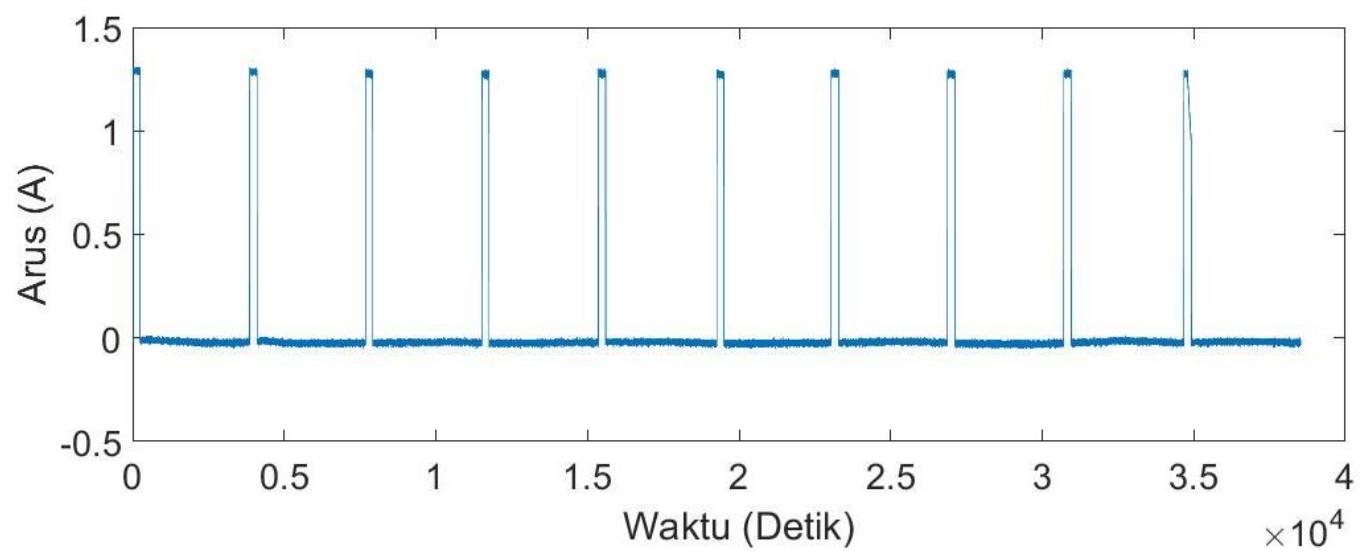

(b)

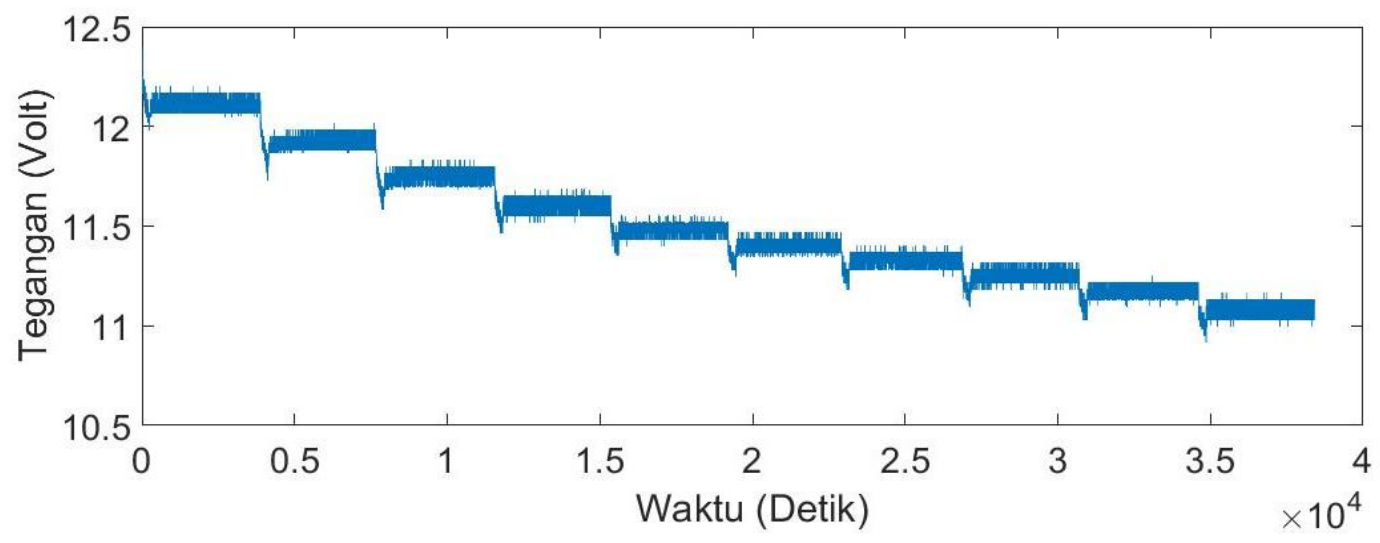

(c) 


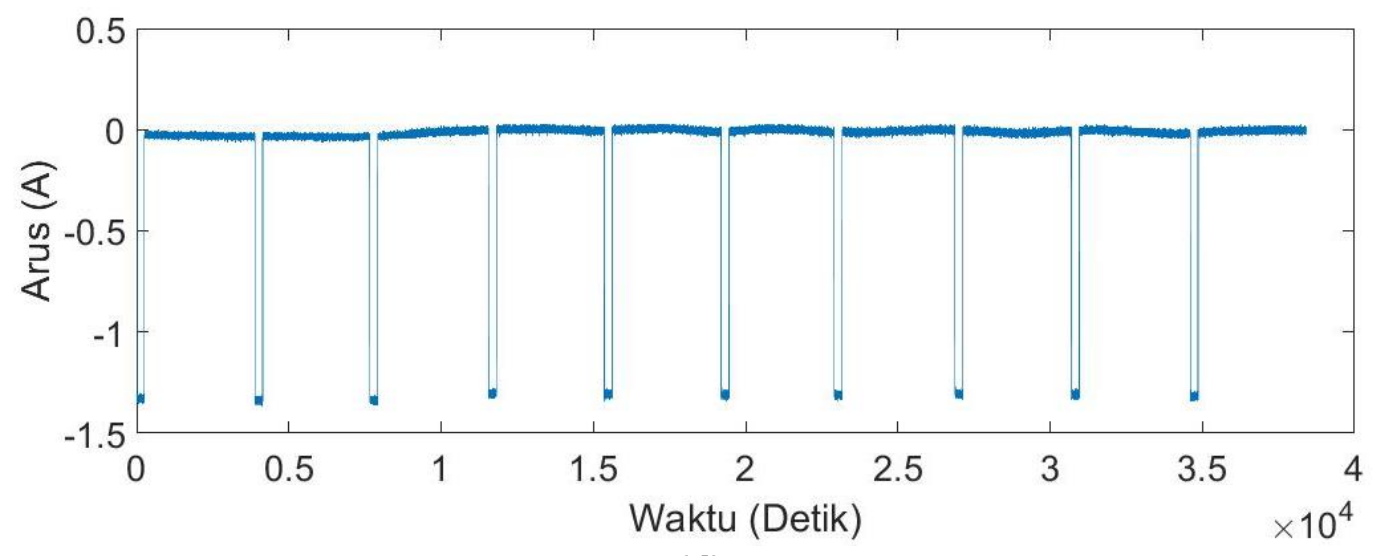

(d)

Gambar 2. Hasil Pengujian Pulsa Baterai (a) Tegangan Charging, (b) Arus Charging, (c) Tegangan Discharging, (d) Arus Discharging

\subsection{Training dan Testing Data Feed Forward Neural Network}

Pada penelitian ini, metode estimasi OCV maupun SOC dilakukan dengan simulasi menggunakan Simulink matlab. Algoritma yang digunakan adalah Feed Forward Neural Network hasil generate nntool setelah dilakukan training (pembelajaran) dari setiap layer. Lavenberg marquart dipilih sebagai metode pembelajaran karena memiliki hasil training lebih baik.

Dalam Neural Network (NN) terdiri dari input layer, hidden layer, dan output layer. Pada penelitian ini menggunakan dual neural untuk estimasi OCV dan SOC. Pada neural yang pertama, input layer FFNN adalah adalah tegangan, arus, dan waktu charging maupun discharging baterai lithium polymer. Jumlah hidden layer yang digunakan sebanyak 1 dengan hidden neuron adalah 11. Jumlah hidden neuron didapatkan dari hasil trial and error training FFNN untuk mendapatkan nilai regression 1 atau mendekati nilai 1 yang tertera pada Gambar 3. Output layer adalah estimasi OCV dengan epoch sebanyak 1000. Epoch 1000 dipilih untuk membatasi lamanya training berlangsung dengan tujuan untuk mendapatkan regression terbaik. Gambar 4 merupakan hasil training estimasi OCV baterai lithium polymer dengan input tegangan, arus, waktu charging maupun discharging.

Neural yang kedua untuk estimasi SOC baterai lithium polymer dengan input layer sebanyak 1 yakni OCV, jumlah hidden layer 1 dengan jumlah hidden neuron sebanyak 4. Output layer adalah SOC baterai berdasarkan kurva karakteristik OCV-SOC. Gambar 5 merupakan arsitektur dari dual neural FFNN yang digunakan pada penelitian ini. 


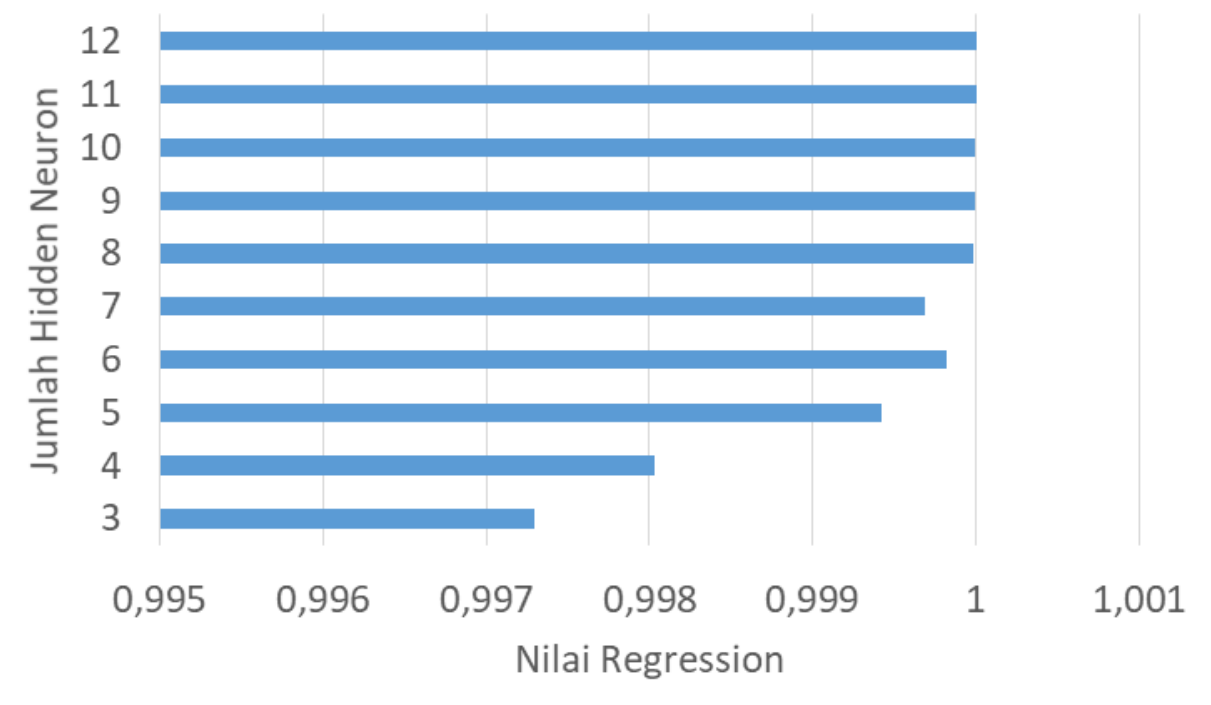

Gambar 3. Nilai Regression Setiap Hidden Neuron
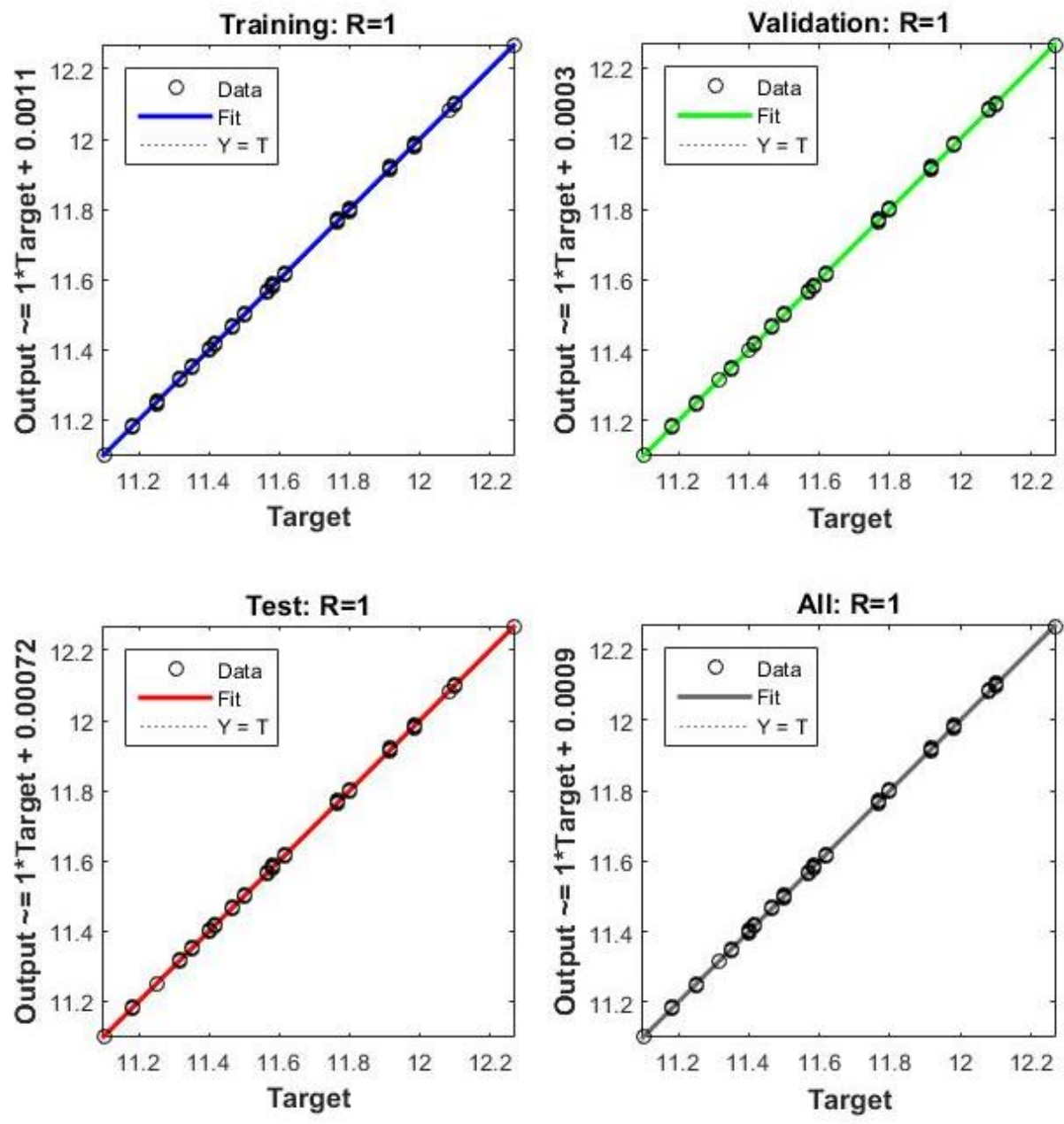

Gambar 4. Hasil Training FFNN Estimasi OCV 


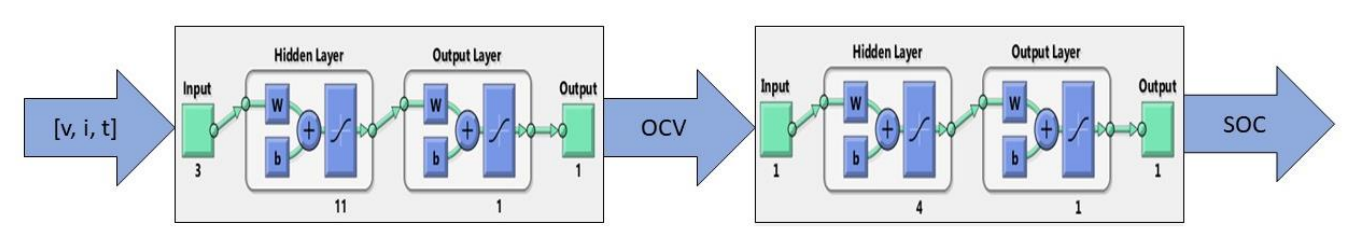

Gambar 5. Arsitektur Dual Neural FFNN

\section{HASIL DAN PEMBAHASAN}

Dari hasil data percobaan pengujian pulsa baterai, dapat diolah berdasarkan beberapa segmen estimasi yakni estimasi OCV dan SOC berdasarkan kurva karakteristik.

\subsection{Kurva Karakteristik OCV-SOC}

Kurva karakteristik OCV-SOC baterai lithium polymer merupakan satu representasi dari ketidaklinieran sistem. Sistem yang demikian memiliki karakter yang uncertainty akibat dari unsur capasitansi kapasitor yang memiliki fungsi charge dan discharge.

Kurva karakteristik OCV-SOC didapatkan dari hasil pengujian pulsa baterai. Sepuluh pulsa yang didapatkan menghasilkan 10 SOC dan 10 OCV baterai. Gambar 6 merupakan karakteristik Kurva karakteristik OCV-SOC baterai lithium polymer.

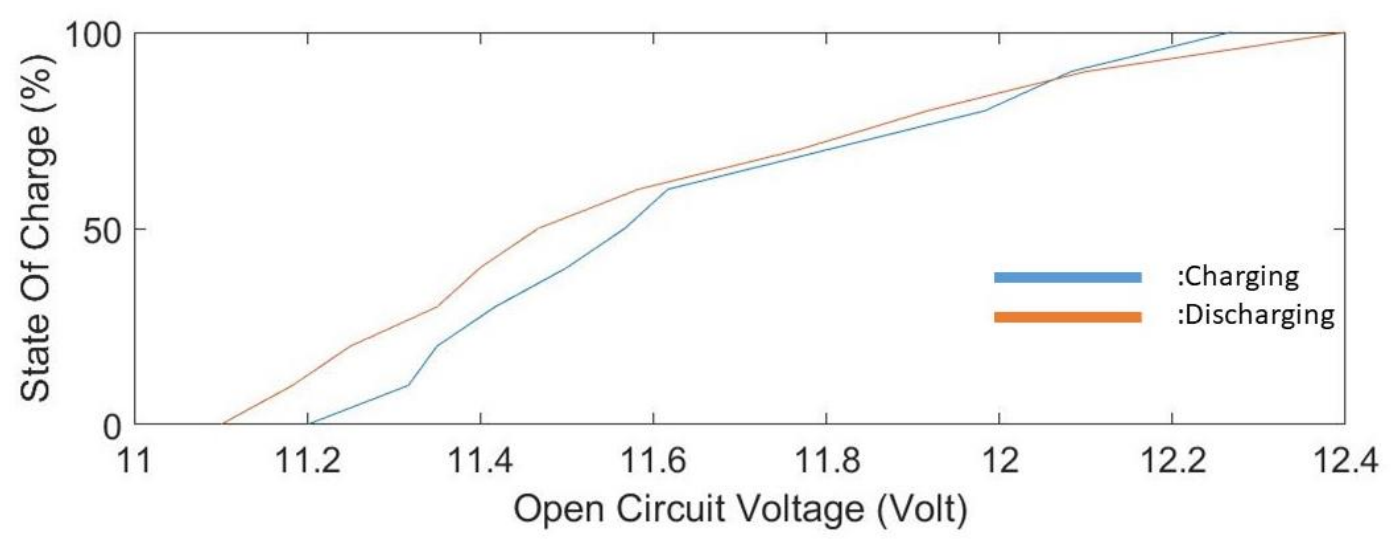

Gambar 6. Kurva karakteristik OCV-SOC Baterai Lithium Polymer

\subsection{Estimasi SOC Baterai Lithium Polymer Menggunakan FFNN}

Dalam penelitian ini estimasi SOC baterai lithium polymer menggunakan FFNN. Input dari FFNN adalah OCV dan target adalah SOC. Input OCV akan dilakukan training antar neuron ke hidden layer sampai dengan output layer. Dari hasil training tersebut didapatkan neural network blok pada Simulink matlab. Untuk memvalidasi dual neural network maka dilakukan pengujian dengan sinyal masukan tegangan, arus, waktu charging maupun discharging. Gambar 7 merupakan hasil simulasi estimasi SOC baterai lithium polymer baik state charge maupun state discharge. 


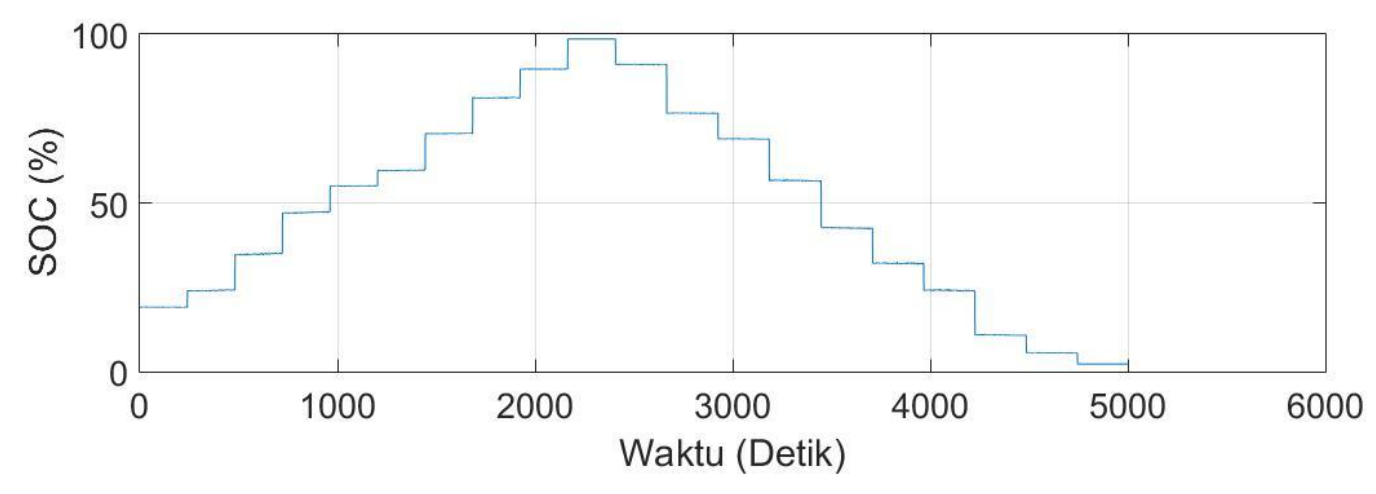

Gambar 7. Hasil Simulasi SOC

\section{SIMPULAN}

Pada penelitian ini, estimasi state of charge baterai lithium polymer menggunakan algoritma feed forward neural network telah didesain dan disimulasikan. Simulasi FFNN yang termasuk kategori soft coumputing ini hanya cukup dilakukan dengan metode learning tanpa harus memodelkan equivalent circuit dari baterai. Penentuan jumlah dari hidden layer FFNN sangat berpengaruh terhadap hasil training. Nilai regression dan MSE sebagai poin indikator hasil training tersebut. Hasil dari training menunjukkan bahwa nilai regression yang dicapai sangat ideal yakni 1 dengan menggunakan jumlah hidden neuron 11.

\section{DAFTAR PUSTAKA}

[1] BPPT, Indonesia Energy Outlook 2018: Sustainable Energy for Land Transportation, vol. 134, no. 4. 2018.

[2] P. Venugopal and T. Vigneswaran, "State-of-charge estimation methods for Li-ion batteries in electric vehicles," Int. J. Innov. Technol. Explor. Eng., vol. 8, no. 7, pp. 37-46, 2019.

[3] C. Youssef, D. Omar, G. Ahmed, E. Fatima, and E. S. Najia, "Design and simulation of an accurate neural network state-of-charge estimator for lithium ion battery pack," Int. Rev. Autom. Control, vol. 10, no. 2, pp. 186-192, 2017.

[4] I. Baccouche, S. Jemmali, A. Mlayah, B. Manai, and N. E. Ben Amara, "Implementation of an improved Coulomb-counting algorithm based on a piecewise SOC-OCV relationship for SOC estimation of Li-ion battery," Int. J. Renew. Energy Res., vol. 8, no. 1, pp. 178-187, 2018.

[5] K. S. Ng, Y. F. Huang, C. S. Moo, and Y. C. Hsieh, "An enhanced coulomb counting method for estimating state-of-charge and state-of-health of leadacid batteries," INTELEC, Int. Telecommun. Energy Conf., pp. 2-6, 2009.

[6] E. Leksono, I. N. Haq, M. Iqbal, F. X. N. Soelami, and I. G. N. Merthayasa, "State of charge (SoC) estimation on LiFePO4 battery module using Coulomb counting methods with modified Peukert," Proc. 2013 Jt. Int. Conf. Rural Inf. Commun. Technol. Electr. Technol. rICT ICEV-T 2013, pp. 4-7, 2013. 
[7] C. Zhang, J. Jiang, L. Zhang, S. Liu, L. Wang, and P. C. Loh, "A generalized SOCOCV model for lithium-ion batteries and the SOC estimation for LNMCO battery," Energies, vol. 9, no. 11, 2016.

[8] F. Liu, T. Liu, and Y. Fu, "An Improved SoC Estimation Algorithm Based on Artificial Neural Network," Proc. - 2015 8th Int. Symp. Comput. Intell. Des. Isc. 2015, vol. 2, pp. 152-155, 2016.

[9] S. Jeon, J. J. Yun, and S. Bae, "Comparative study on the battery state-ofcharge estimation method," Indian J. Sci. Technol., vol. 8, no. 26, pp. 1-6, 2015. 